\title{
Studies on the Operational Parameters of Sugarcane Harvesting Blades
}

\author{
Prerana Priyadarsini Jena ${ }^{1^{*}}$, Nrushinhananda Mahapatra ${ }^{1}$, \\ Suryakanta Khandai ${ }^{2}$ and Debaraj Behera ${ }^{1}$ \\ ${ }^{1}$ Department of Farm Machinery and Power, CAET, OUAT, Bhubaneswar, \\ Odisha-751003, India \\ ${ }^{2}$ Department of Farm Machinery and Power Engineering, Sam Higginbottom University of \\ Agriculture, Technology and Sciences, Allahabad - 211007, (U.P.), India \\ *Corresponding author
}

\begin{tabular}{|l|}
\hline K e y w o r d s \\
$\begin{array}{l}\text { Vertical rotor set up, } \\
\text { Cutting blade inclination } \\
\text { angle, Brix value, Cane } \\
\text { diameter, Cutting torque, } \\
\text { Cutting force, Power } \\
\text { requirement }\end{array}$ \\
\hline Article Info \\
\hline $\begin{array}{l}\text { Accepted: } \\
\text { 10 February } 2018 \\
\text { Available Online: } \\
\text { 10 March } 2018\end{array}$ \\
\hline
\end{tabular}

In India, there is a need for a small scale sugarcane harvesting machine which can be used by small and marginal farm holders. The present work has been taken to develop a suitable harvesting machine/ attachment which can be power tiller attached and operated by a multi -purpose tool carrier; for the small and marginal farmers. The developed test set up consisted of a vertical rotor shaft for holding the cutting blade to achieve desired height of cut of cane, the bevel gear unit, the power drive and frame work. The test was conducted with three cutting blade inclination angles $\left(0^{\circ}, 15^{\circ}, 30^{\circ}\right)$, three cane diameters $(20 \pm 2$, $25 \pm 2,30 \pm 2$ ) $\mathrm{mm}$ at constant speed of travel $0.8 \mathrm{~km} / \mathrm{h}$, cutting speed $700 \mathrm{rpm}$, brix value of 16-18 degree for Raghunath variety of sugarcane. The result showed that the vertical rotor set up developed can be successfully used in the test soil bin and the base cutting of sugarcane can be successfully obtained with varying cutting blade and cane parameters. For $30^{\circ}$ cutting blade inclination angle, the power requirement of prime mover for cutting a single cane of $20 \pm 2,25 \pm 2$ and $30 \pm 2 \mathrm{~mm}$ diameter was $0.290 \mathrm{~kW}, 0.339 \mathrm{~kW}$ and $0.416 \mathrm{~kW}$, respectively. The research findings are expected to provide necessary information for development of a low cost sugarcane harvester suitable for mounting on power tiller or multi-purpose tool carriers. Depending on the power source, number of cutting blades can be used to cover multiple rows.

\section{Introduction}

Sugarcane is one of the oldest crops known to man, a major crop of tropical and sub-tropical regions worldwide. World crop production database FAO (2013) reveals that the global sugarcane production was 448 million tonnes produced from 8.91 million hectares, with the average productivity of just over 50 tonnes per hectare during 1960's. In nut shell, the global sugarcane production had a nearly four times increase and sugarcane area increased by 2.8 times during last five decades (1961 to 2012). Brazil is the major sugarcane producing country with an area about 90.77 lakh hectare and production of about 717.46 Million ton followed by India. Sugarcane is the most important cash crop of India. It involves less risk and farmers are assured up to some extent about return even in adverse condition. In 
agriculture sector, sugarcane shared 7 per cent of the total value of agriculture output and occupied 2.6 per cent of India's gross cropped area during 2006-07. In India, sugarcane is cultivated over an area of 5.15 million hectare with an annual production of 355.52 million tones and productivity 69t/ha whereas in Odisha total area under sugarcane is of 35.34 thousand hectares with a production of 2543.79 thousand MT and yield of $72 \mathrm{t} / \mathrm{ha}$ in Odisha.

Harvesting and collection of cane can be either manual or mechanical. In manual harvesting, 15-16 labours take them 3 days to cut one acre and harvest of 60-70 tons per acre with labours being paid 500-550 rupees per ton of harvest; hence total cost of harvesting per acre comes up to $30,000-35,000$ rupees. Sugarcane harvester is an agricultural machinery used to harvest and process cane. In mechanization now, large scale harvesting machines take about 6-7 hours for harvesting one acre averaging about 60-70 tons with costing around 3,500-4,000 rupees per hour; hence the total cost of harvesting per acre comes up to $20,000-25,000$ rupees. It has been found that cane is harvested and gathered mechanically, by combine harvester, or manually cut, collected and then grab loaded into large trucks/ tractor trolley. In the manual system of harvesting using a straight blade knife, generally $5-10 \mathrm{~cm}$ piece of stable is left above the ground. It has been found that knife with a curved blade is much superior to straight knife in harvesting sugarcane sticks in flush with the ground. The sugarcane harvester is used in tropical parts of the country for sugarcane harvesting. Mechanical sugarcane harvesters costing more than ten lakhs are used mostly by large farm holders to overcome human drudgery. However, there is a need for a small scale sugarcane harvesting machine which can be used by small and marginal farm holders. Harvesting of sugarcane at proper time i.e., peak maturity, by adopting right technique is necessary to realize maximum weight of the millable canes (thus sugar) produced with least possible field losses under the given growing environment while improper method of harvesting leads to loss in cane yield, sugar recovery, poor juice quality and problems in milling due to extraneous matter. On the basis of the above, the present work has been taken to develop a suitable harvesting machine/ attachment which can be power tiller attached and operated by a multi -purpose tool carrier; for the small and marginal farmers of the state with the objective to develop a vertical rotor set up and to study the cutting blade and cane parameter in test soil bin to find out the power requirement for cutting of sugarcane.

\section{Materials and Methods}

The lab test was conducted in test soil bin which has different speeds of operation by choosing suitable gears of a gear reduction unit coupled to the input shaft of the revolving drum, which was attached to soil processing trolley with stainless-steel rope. A control unit, placed outside the soil bin, controlled the direction of movement of the soil processing trolley (Khandai et al., 2015).

\section{Development of vertical rotor set up}

A vertical set up was designed for small and marginal farmers which can be attached in power tiller and can be used as a multipurpose tool carrier. The setup is designed as per specification given in the table and fitted to test soil bin and the base cutting of sugarcane could be successfully obtained with varying cutting blade and cane parameters (Jena, 2017).

To hold the sugarcanes for cutting, frames were fabricated in order to avoid the lodging of canes while it was being cut by cutting blade. Three such frames were fixed in the test 
set up for cutting sugarcanes as shown in the figure. The cutter blade used in the set cutter planter has been used in this study. However, the cutter blade inclination angles have been maintained at three levels of $0^{\circ}, 15^{\circ}$, and $30^{\circ}$. Height of the cut of sugarcane was maintained at $5 \mathrm{~cm}$ above the ground level.

\section{Torque measurement}

For measurement of torque, a torque transducer fitted on the shaft of the driving motor was used. The torque required to drive the rotor shaft was measured which was displayed on the monitor through data acquisition system.

\section{Quality parameters}

Important sugarcane quality parameters for assessing cane maturity are the juice Brix, pol or sucrose percentage and purity. Juice Brix refers to the total solids content present in the juice expressed in percentage. Brix includes sugars as well as non-sugars. Brix can be measured in the field itself in the standing cane crop using a Hand Refractometer. This is usually referred as a Hand Refractometer Brix or HR Brix. In the field using a pierce collect composite juice samples from several canes. Then place a drop of the composite juice sample in the Hand Refractometer and measure the Brix reading. The circular field gets darkened relative to the brix level, which could be easily read. The HR brix readings can be separately taken from both top and bottom. A narrow range indicates ripeness of the cane, while a wide difference indicates that the cane is yet too ripe. On the other hand if the bottom portion of the cane has lower Brix value than the top, it means that the cane is over ripened and reversion of sugar is taking place. The sugarcane tested for the cutting strength and torque requirement confirmed to the brix value of 17-19 degree brix which is within the acceptable range.

\section{Calculation for cutting force and power}

Motor torque x motor rpm x 0.95 x 0.95 x $0.95=$ rotor $\mathrm{rpm} \times$ rotor torque

(V Belt drive transmission efficiency $=0.95$ )

Rotor torque $($ in $\mathrm{N}-\mathrm{m})=$ motor torque $\mathrm{x}$ motor rpm $x(0.95)^{3} /$ rotor $\mathrm{rpm}$

Cutting Force $($ in $\mathrm{N})=$ rotor torque $/$ effective blade radius

(Effective radius of cutter blade $=168 \mathrm{~mm}=$ $0.168 \mathrm{~m}$ )

Power requirement of the rotor $=2 \times \pi \times$ rotor rpm $\mathrm{x}$ rotor torque $/ 60,000$

Power requirement of the source $=$ Power requirement of rotor/ $(0.95)^{3}$

\section{Results and Discussion}

The effects of machine parameters and crop parameters on cutting torque, cutting force and power requirement for base cutting of sugarcane are discussed in the following.

\section{Effect of cutting blade inclination angle}

The results obtained for three cutting blade inclination angles such as $0^{\circ}, 15^{\circ}$ and $30^{\circ}$ are given in following table and the graph shown its result.

Effect of blade inclination angle on cutting torque, cutting force and power requirement of prime mover for different cane diameter

The data that indicate within the test range, the torque and power requirement was highest at $0^{\circ}$ cutting blade inclination angle and lowest at $30^{\circ}$ cutting blade inclination angle for all the three diameters of cane. 
Effect of cane diameter and cutting blade inclination angle on motor torque, cutting torque, cutting force, power requirement by rotor shaft and

Power requirement by prime mover

\begin{tabular}{|c|c|c|c|c|c|c|}
\hline $\begin{array}{l}\text { Cane } \\
\text { diameter, } \\
\text { Mm }\end{array}$ & $\begin{array}{l}\text { Blade } \\
\text { inclination } \\
\text { angle, }^{\circ}\end{array}$ & $\begin{array}{l}\text { Motor } \\
\text { torque, } \\
\text { N-m }\end{array}$ & $\begin{array}{l}\text { Cutting } \\
\text { torque, } \\
\text { N-m }\end{array}$ & $\begin{array}{l}\text { Cutting } \\
\text { force, } \\
\text { N }\end{array}$ & $\begin{array}{l}\text { Power } \\
\text { requirement by } \\
\text { rotor shaft, } \mathrm{kW} \\
\end{array}$ & $\begin{array}{l}\text { Power } \\
\text { requirement by } \\
\text { prime mover, } \mathrm{kW}\end{array}$ \\
\hline \multirow{3}{*}{$20 \pm 2$} & 0 & 7.128 & 5.255 & 31.10 & 0.385 & 0.449 \\
\hline & 15 & 5.736 & 4.229 & 25.17 & 0.310 & 0.361 \\
\hline & 30 & 4.624 & 3.409 & 20.29 & 0.249 & 0.290 \\
\hline \multirow{3}{*}{$25 \pm 2$} & 0 & 8.523 & 6.284 & 37.40 & 0.460 & 0.536 \\
\hline & 15 & 6.772 & 4.993 & 29.70 & 0.366 & 0.426 \\
\hline & 30 & 5.390 & 3.974 & 23.65 & 0.291 & 0.339 \\
\hline \multirow{3}{*}{$30 \pm 2$} & 0 & 10.546 & 7.776 & 46.28 & 0.570 & 0.664 \\
\hline & 15 & 8.524 & 6.285 & 37.41 & 0.460 & 0.536 \\
\hline & 30 & 6.616 & 4.878 & 29.03 & 0.357 & 0.416 \\
\hline
\end{tabular}

Components of the assembly and their specification

\begin{tabular}{|l|l|l|}
\hline SI. No. & Materials with Specification & Dimension \\
\hline 1 & M S Angle $(65 \times 65 \times 6) \mathrm{mm}$ & $3500 \mathrm{~mm}$ \\
\hline 2 & M S Angle $(40 \times 40 \times 5) \mathrm{mm}$ & $6500 \mathrm{~mm}$ \\
\hline 3 & Shaft $(25 \mathrm{~mm})$ & $1200 \mathrm{~mm}$ \\
\hline 4 & Bearing with housing $(25 \mathrm{~mm})$ & 4 nos. \\
\hline 5 & Nuts and Bolts $(2 " \times 1 / 2 ")$ & 12 nos. \\
\hline 6 & Bevel Gear Box & 1 set \\
\hline 7 & V-Pulley B groove & 4 nos. \\
\hline 8 & V-Belt & 3 nos. \\
\hline
\end{tabular}
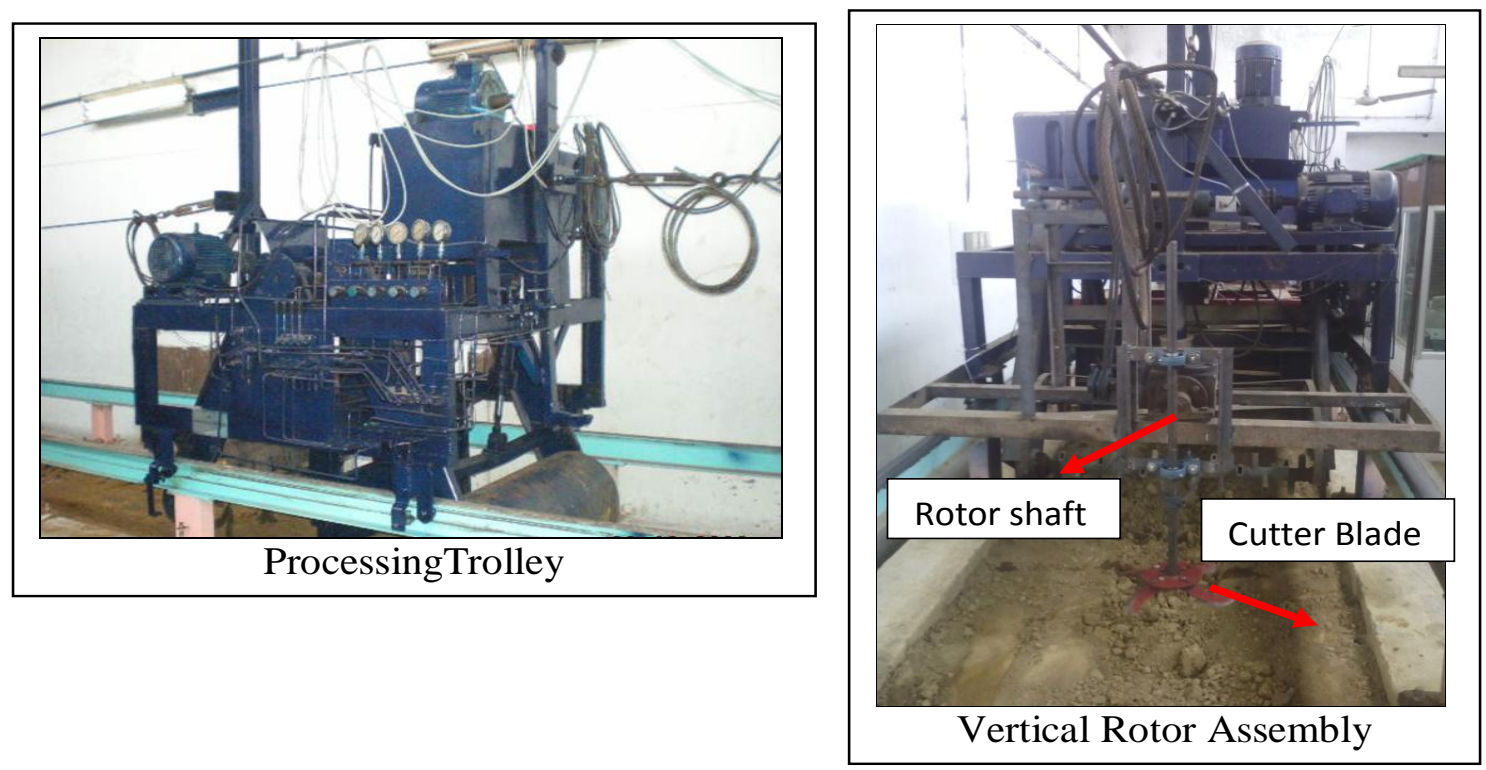


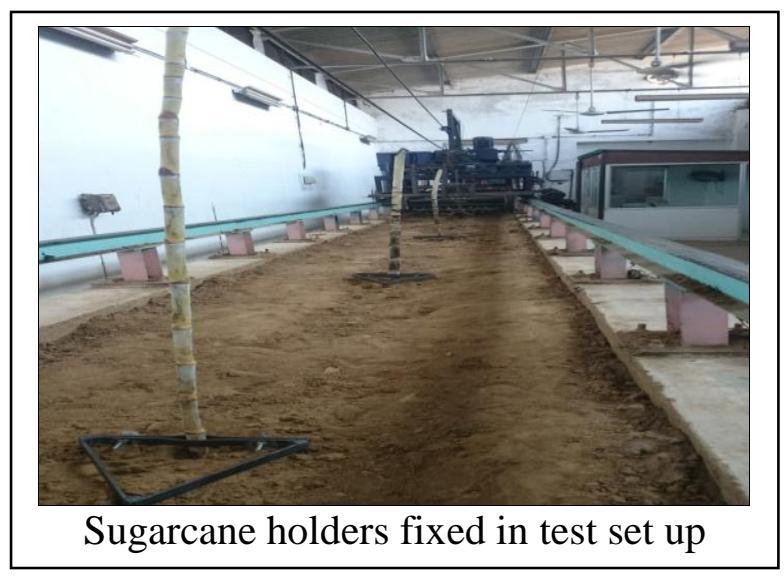

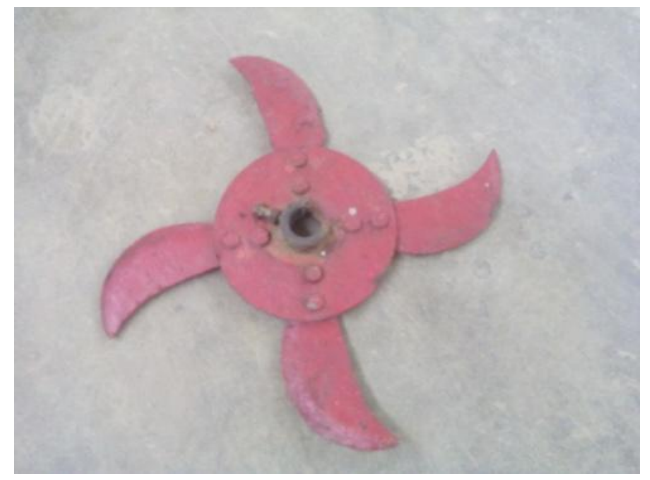

Inclination angle $=0^{\circ}$

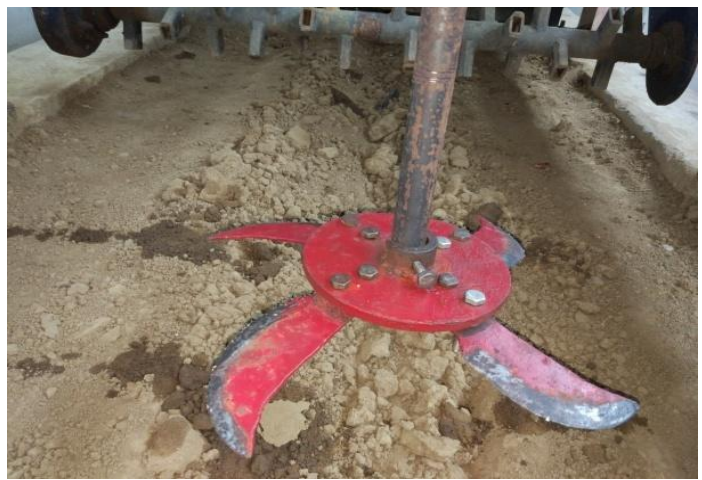

Inclination angle $=30^{\circ}$

Effect of blade inclination angle on cutting torque, cutting force and power requirement of prime mover for different cane diameter

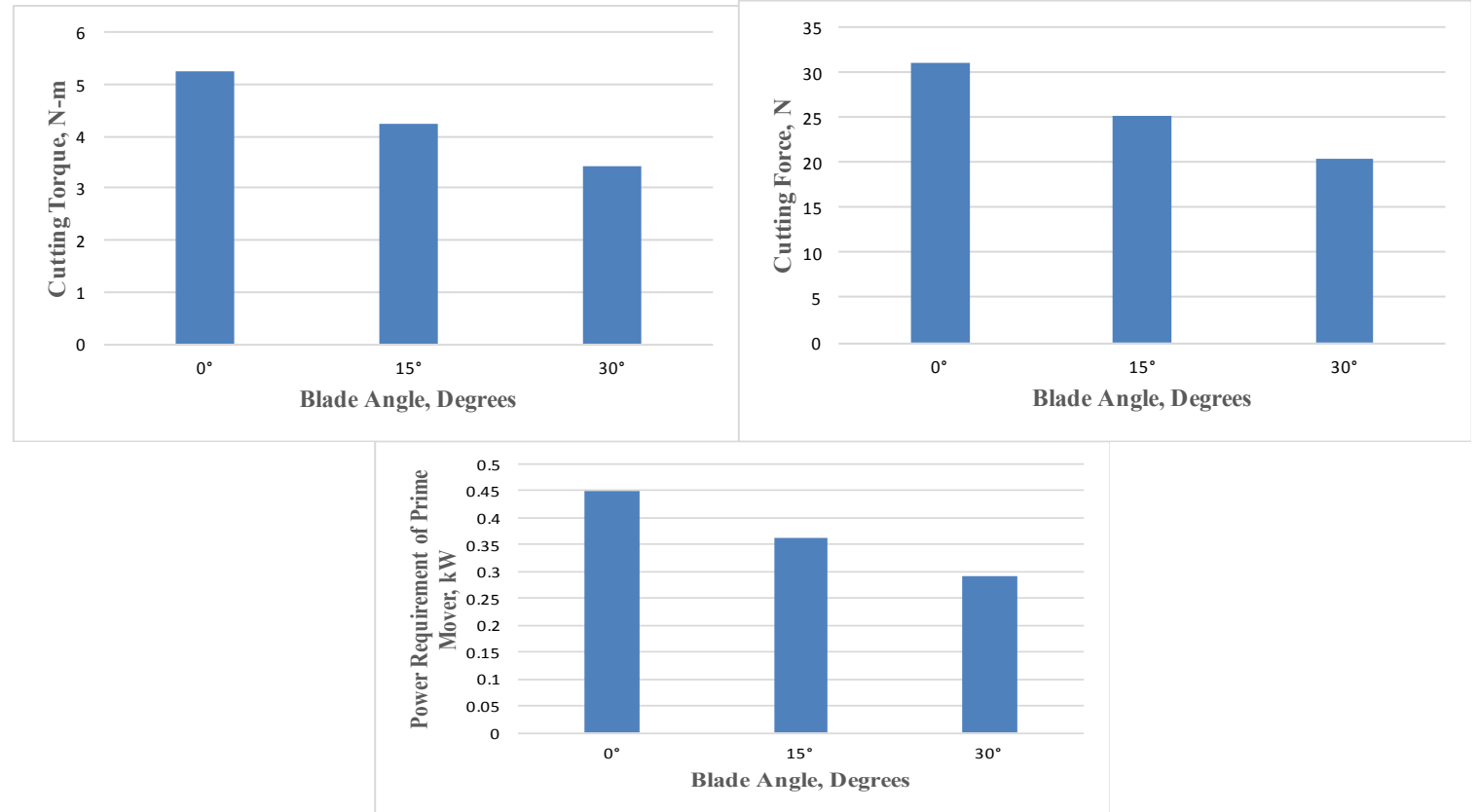

For $20 \pm 2 \mathrm{~mm}$ cane diameter 
Int.J.Curr.Microbiol.App.Sci (2018) 7(3): 1163-1172
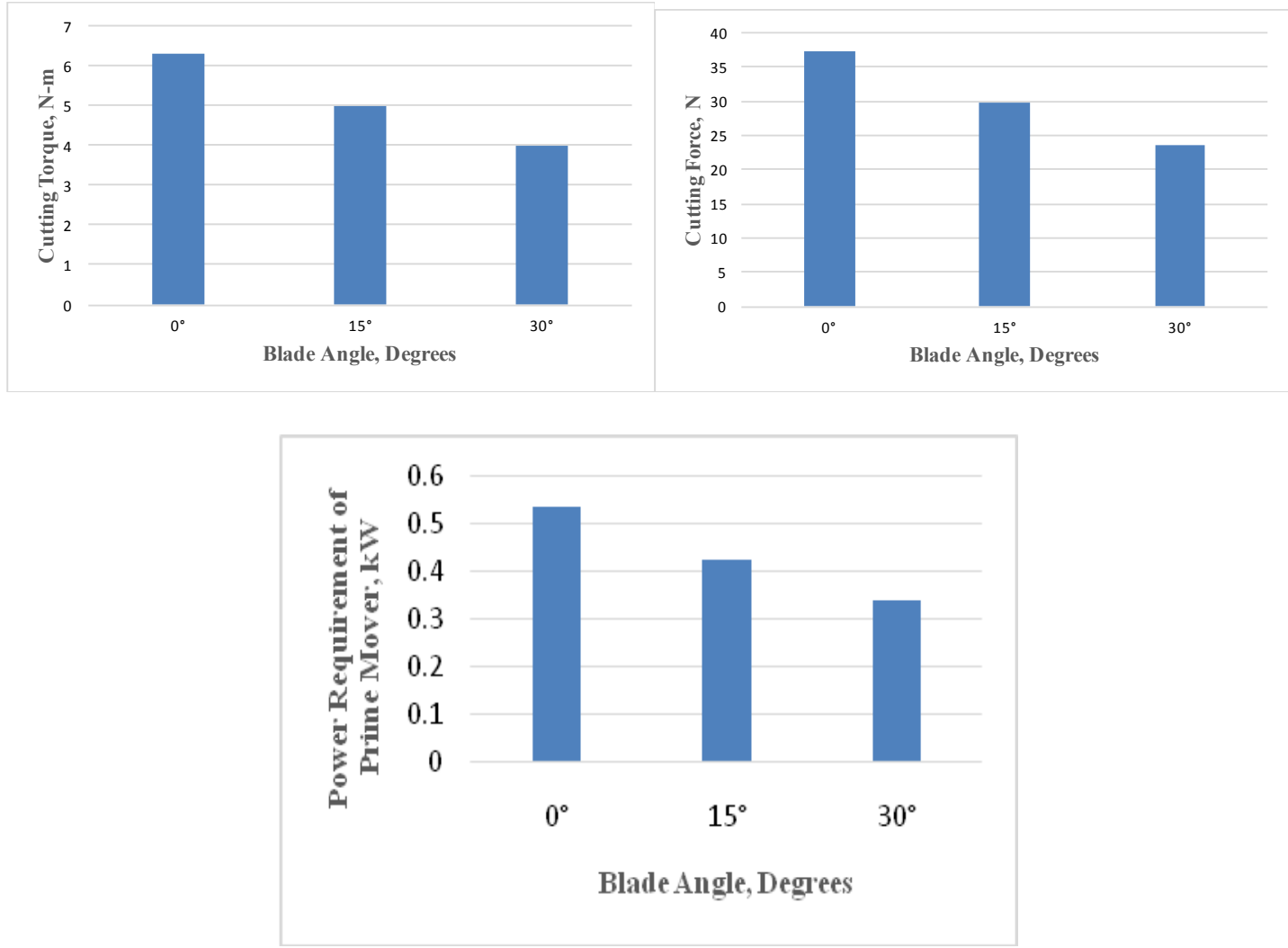

For $25 \pm 2 \mathrm{~mm}$ cane diameter
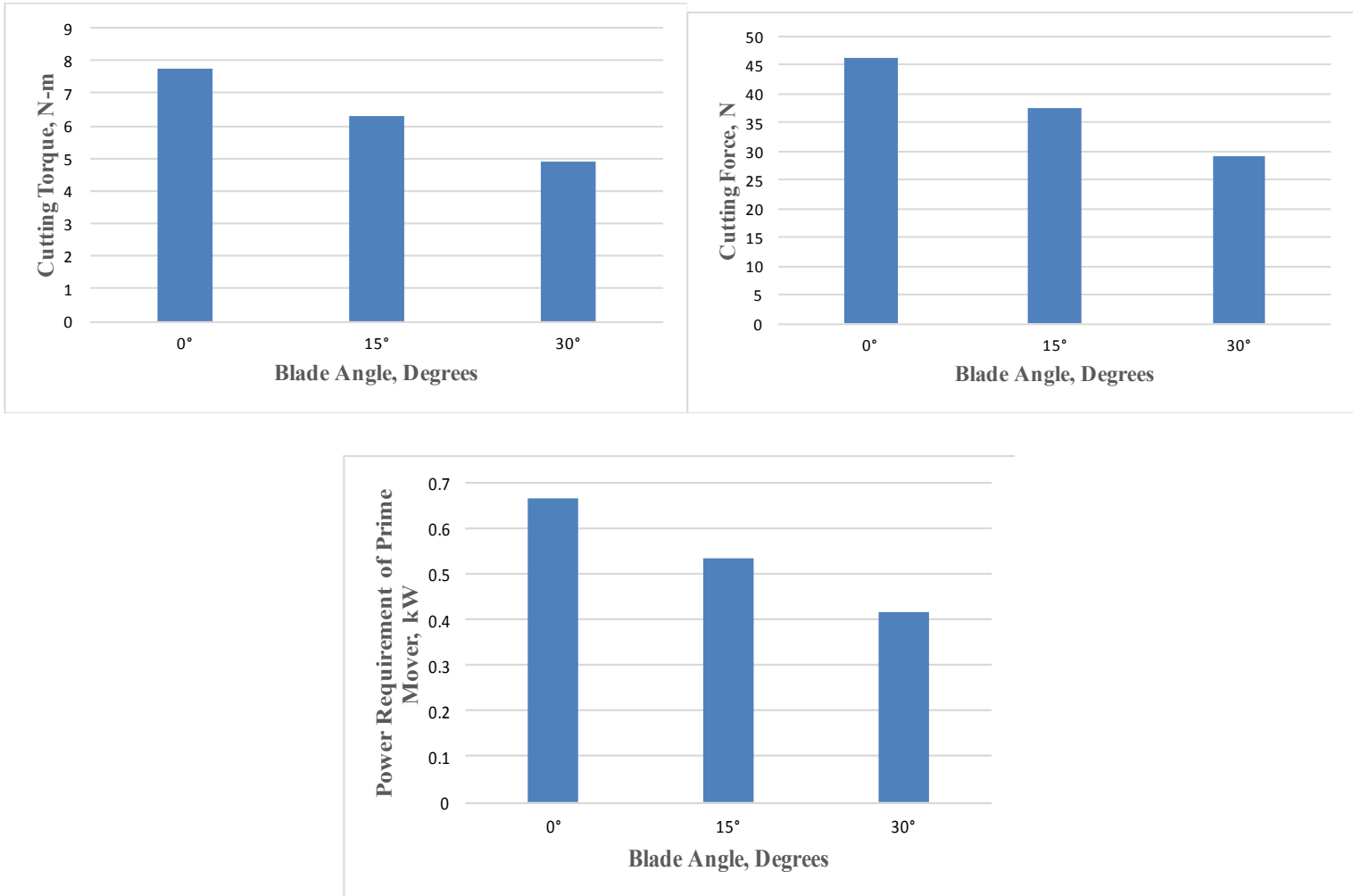

For $30 \pm 2 \mathrm{~mm}$ cane diameter 
Effect of cane diameter on cutting torque, cutting force and power requirement of prime mover at different cutting blade inclination angle

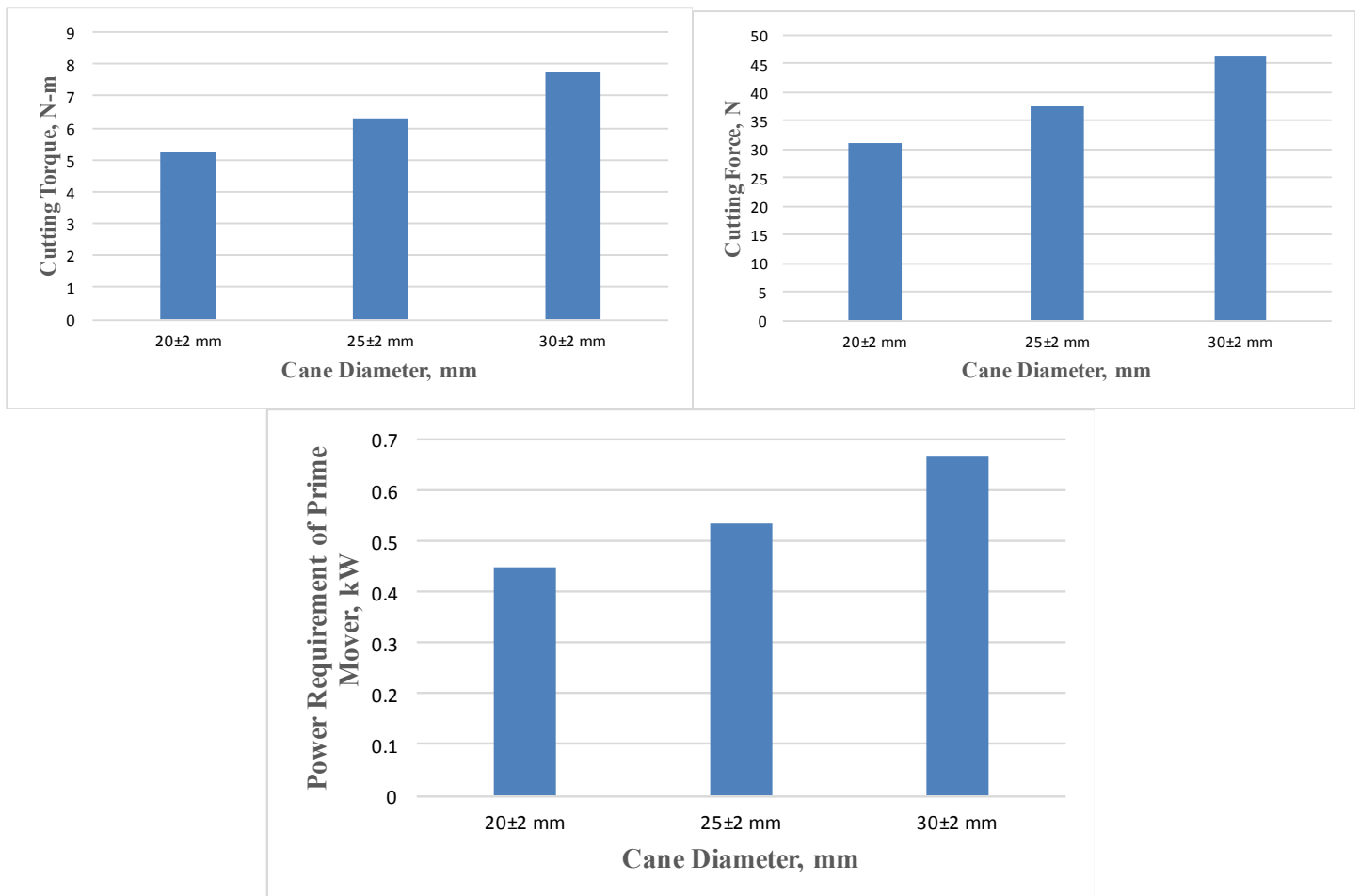

For $0^{\circ}$ blade inclination angle
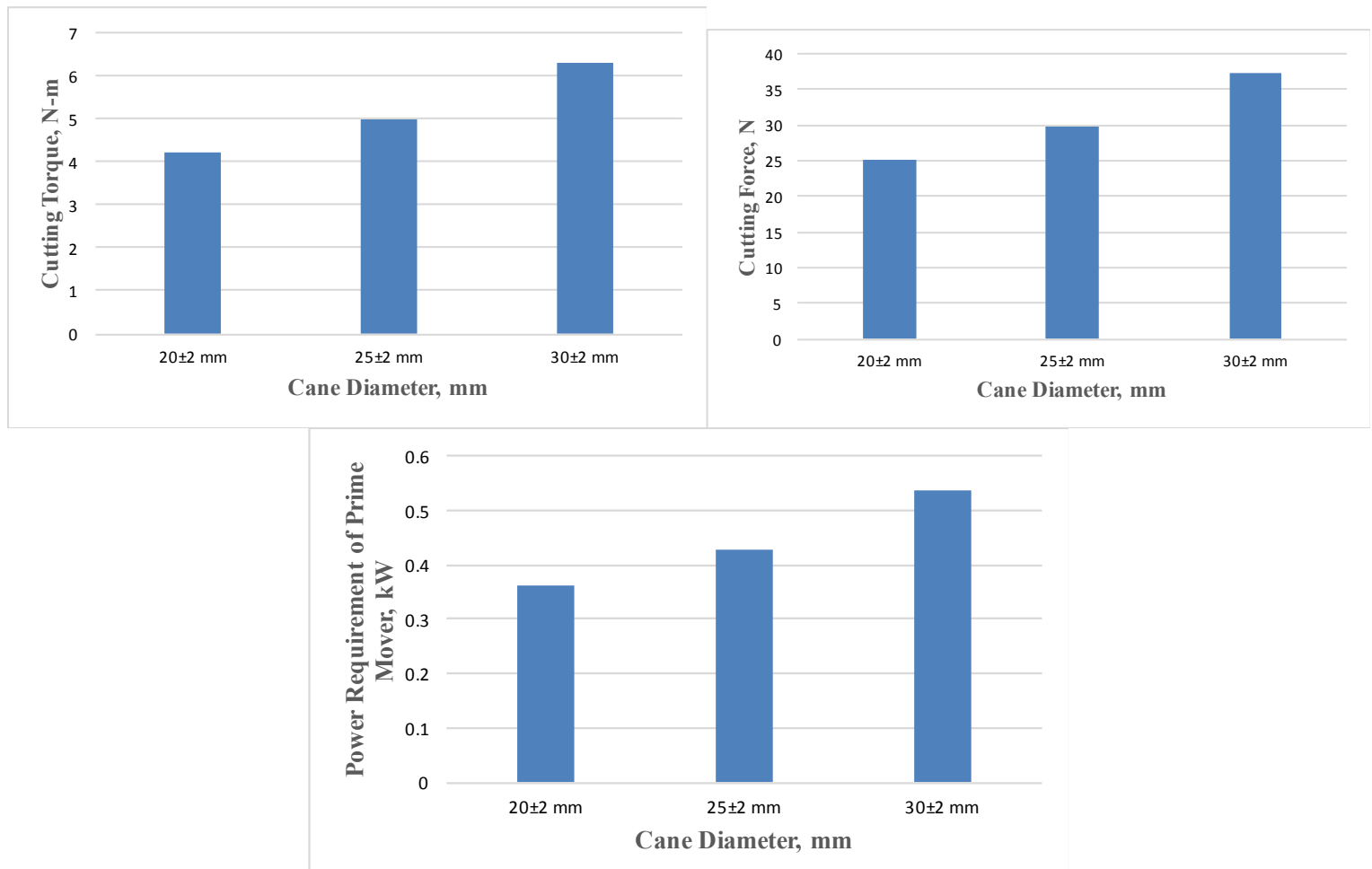

For $15^{\circ}$ blade inclination angle 


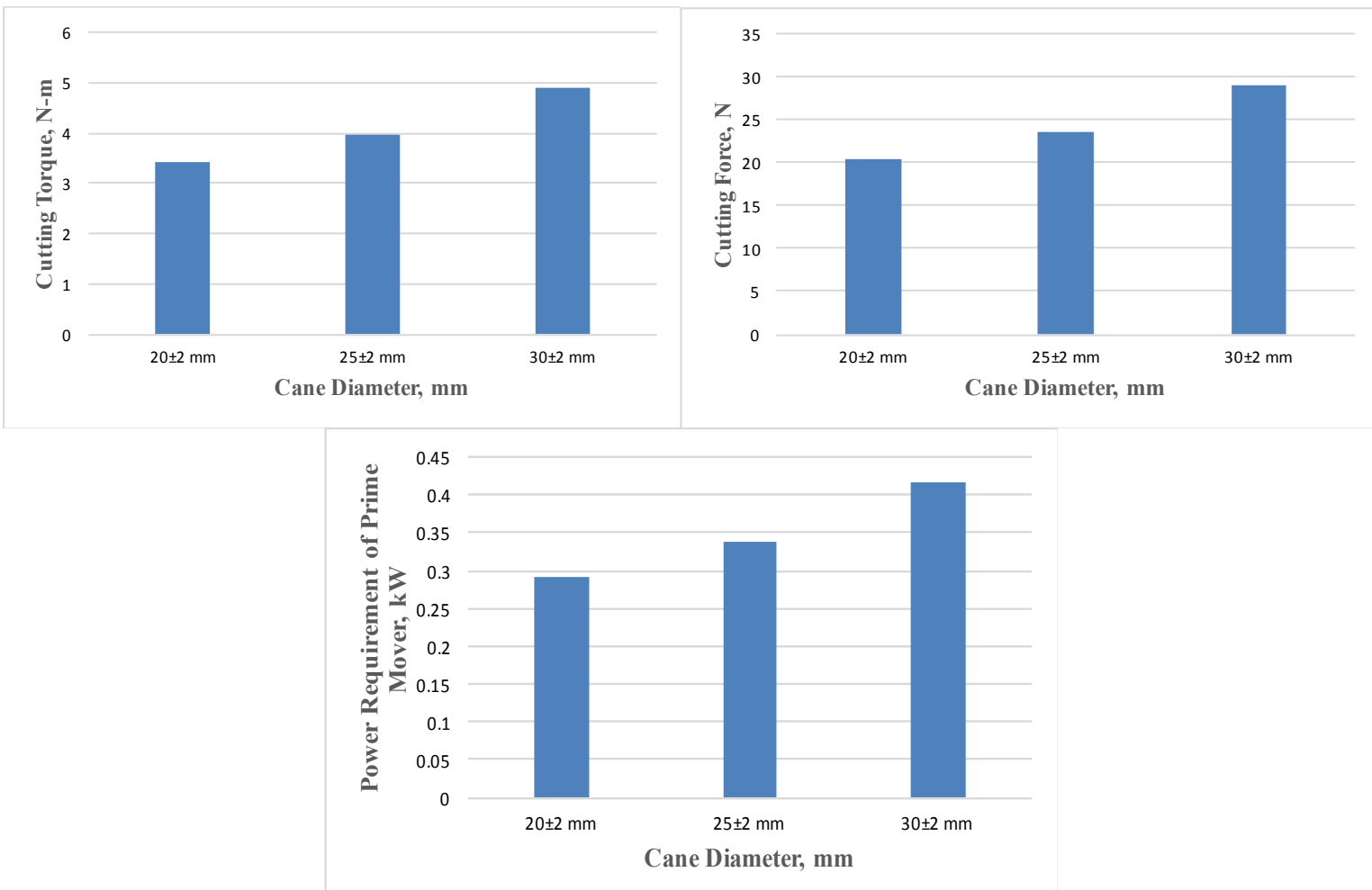

For $30^{\circ}$ blade inclination angle

Effect of blade inclination angle and cane diameter for power requirement

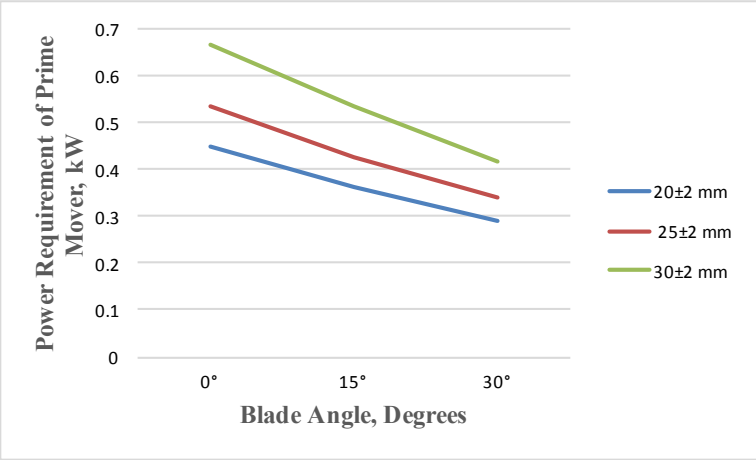

This shows that lowest cutting force was required due to less cutting resistance of sugarcane base. This is in agreement with the findings of Jhonson et al., (2012) for energycane.

\section{Effect of cane diameter}

The results obtained for three cane diameters such as $20 \pm 2 \mathrm{~mm}, 25 \pm 2 \mathrm{~mm}$ and $30 \pm 2 \mathrm{~mm}$ are given as following.

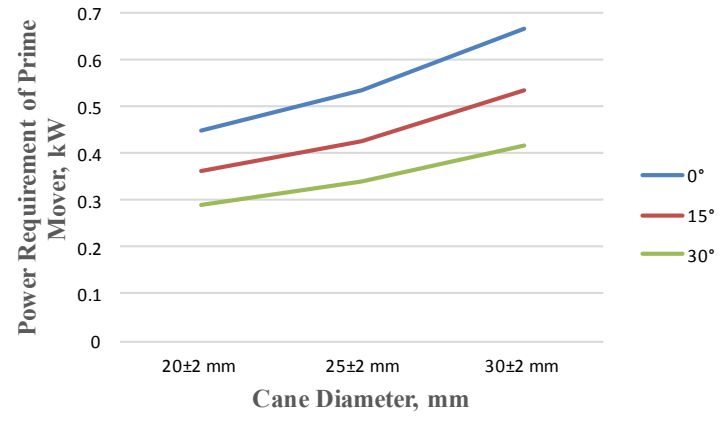

Effect of cane diameter on cutting torque, cutting force and power requirement of prime mover at different cutting blade inclination angle

The experimental data reveals that the cutting force, cutting torque and power requirement increased with the cane diameters for all the three cutting blade inclination angles. The lowest values of the cutting parameters were observed for $20 \pm 2 \mathrm{~mm}$ diameter cane which 
was due to least cutting resistance. Lowest value for cutting torque $(3.409 \mathrm{~N}-\mathrm{m})$, cutting force $(20.29 \mathrm{~N})$, power requirement $(0.29$ $\mathrm{kW})$ were observed for cane diameter $20 \pm 2$ $\mathrm{mm}$ at $30^{\circ}$ cutting blade inclination angle, whereas, highest value of cutting torque (7.776 N-m), cutting force $(46.28 \mathrm{~N})$, power requirement $(0.664 \mathrm{~kW})$ were observed for cane diameter $30 \pm 2 \mathrm{~mm}$ at $0^{\circ}$ cutting blade inclination angle.

\section{Power requirement}

From the above study on power requirement for base cutting of sugarcane with three different cutting blade angles and three different cane diameters, it was observed that for a single cane of $30 \pm 2 \mathrm{~mm}$ diameter and $30^{\circ}$ cutting blade inclination angle, the power requirement of prime mover was $0.416 \mathrm{~kW}$.

The research findings of the above study provide useful information for development of a small scale sugarcane harvesting machine.

In this research work a vertical rotor assembly developed and fabricated, was mounted on the main frame of the processing trolley. To hold the sugarcanes for cutting, frames were fabricated in order to avoid the lodging of canes while it was being cut by cutter blade. The test was conducted with three cutting blade inclination angles $\left(0^{\circ}, 15^{\circ}, 30^{\circ}\right)$, three cane diameters $(20 \pm 2,25 \pm 2,30 \pm 2) \mathrm{mm}$ at constant speed of travel $0.8 \mathrm{~km} / \mathrm{h}$, cutting speed $700 \mathrm{rpm}$ (Das et.al., 1972), brix value of 16-18 degree for Raghunath variety.

The major conclusions drawn from the study are given below:

The vertical rotor set up developed can be successfully used in the test soil bin and the base cutting of sugarcane can be successfully obtained with varying cutting blade and cane parameters. Within the test range, the torque and power requirement was highest at $0^{\circ}$ cutting blade inclination angle and lowest at $30^{\circ}$ cutting blade inclination angle for all the three diameters of cane.

The cutting force, cutting torque and power requirement increased with the cane diameters for all the three cutting blade inclination angles.

For $30^{\circ}$ cutting blade inclination angle, the power requirement of prime mover for cutting a single cane of $20 \pm 2,25 \pm 2$ and $30 \pm 2 \mathrm{~mm}$ diameter was $0.290 \mathrm{~kW}, 0.339 \mathrm{~kW}$ and 0.416 $\mathrm{kW}$, respectively.

The research findings are expected to provide necessary information for development of a low cost sugarcane harvester suitable for mounting on power tiller or multi-purpose tool carriers. Depending on the power source, number of cutting blades can be used to cover multiple rows.

\section{References}

Das FC and Gupta CP. 1972. Cutting resistance of sugar cane stem. Presented at the 10th annual meeting of Indian Society of Agricultural Engineers at Jabalpur, India, 3-5 Feb.

Jena, Prerana Priyadarsini. 2017. Studies on the Operational Parameters of Sugarcane Harvesting Blades, Unpublished M.Tech. Thesis. Department of Farm Machinery and Power, OUAT, Bhubaneswar, Odisha.

Johnson P.C., Clementson C.L., Mathanker S.K., Grift T.E., and Hansen A.C. 2012. Cutting energy characteristics of Miscanthus $\mathrm{x}$ giganteus stems with varying oblique angle and cutting speed, Biosystems Engineering, 112: 42-48.

Khandai S., Mahapatra N., and Ghosal M.K., Development of a Shoe Attachment to 
the Existing Furrow Opener of Tractor Drawn Seed cum Fertilizer Drill and its Performance Evaluation, International
Journal of Scientific \& Engineering Research, Volume 6, Issue 11, November-2015, page: 1082-1089.

\section{How to cite this article:}

Prerana Priyadarsini Jena, Nrushinhananda Mahapatra, Suryakanta Khandai and Debaraj Behera. 2018. Studies on the Operational Parameters of Sugarcane Harvesting Blades. Int.J.Curr.Microbiol.App.Sci. 7(03): 1163-1172. doi: https://doi.org/10.20546/ijcmas.2018.703.138 